\title{
THE INFLUENCE OF COMBINATIONS OF OPERATION PARAMETERS ON SEWAGE TREATMENT IN VERTICAL-FLOW CONSTRUCTED WETLANDS
}

\author{
XU, Q. L. ${ }^{1 *}-$ YUAN, T. ${ }^{2}-$ QIAO, Z. W. ${ }^{1}-$ WANG, P. ${ }^{1}-$ WANG, L. ${ }^{1}-$ ZhANG, F. ${ }^{1}$ \\ ${ }^{1}$ Department of Resources \& Environmental Engineering, Anshun University, Anshun 561000, \\ Guizhou, PR China \\ ${ }^{2}$ State Key Laboratory of Nuclear Resources and Environment, East China University of \\ Technology, Nanchang 330013, Jiangxi, PR China \\ *Corresponding author \\ e-mail: amy.198510@163.com; phone: +86-189-8408-9040
}

(Received $18^{\text {th }}$ Mar 2020; accepted $20^{\text {th }}$ Aug 2020)

\begin{abstract}
This paper aims to research the relationship between design parameters and purification effect. An Orthogonal experiment was conducted on the aeration mode, hydraulic load rate and organic load, to study the influence of operation parameters on the pollutant removal rate and substrate enzyme activities of vertical-flow constructed wetlands. These results revealed that the best treatment under the conditions of $20 \mathrm{~cm} / \mathrm{d}$ hydraulic, $60 \mathrm{~g} /\left(\mathrm{m}^{2} \cdot \mathrm{d}\right)$ organic load and intermittent aeration has outstanding decontamination performance and the removal efficiency of total nitrogen, total phosphorous and chemical oxygen demand reached $61 \%, 31 \%$ and $92 \%$, respectively. It was higher than those of other treatments significantly $(\mathrm{p}<0.05)$, indicating that proper improvement of organic load, reduction of hydraulic load and auxiliary intermittent aeration were beneficial to the improvement of sewage removal capacity of vertical flow constructed wetland. By analyzing the correlation of pollutant removal efficiency and enzyme activity, urease and catalase appear to have significant correlation with total nitrogen removal efficiency $(\mathrm{p}<0.01)$, while catalase appear to have significant correlation to chemical oxygen demand removal efficiency $(p<0.01)$. The results for the use of enzymes as evaluation indices for the purification effect and the improvement of the decontamination capability in vertical-flow constructed wetland provides a theoretical basis.
\end{abstract}

Keywords: vertical-flow constructed wetland, orthogonal experiment, operation parameters, enzyme, removal efficiency

\section{Introduction}

Constructed Wetlands (CW) are used extensively for the removal of contaminants from sewage, improving the environment in the world. Compared with traditional sewage treatment technologies, $\mathrm{CW}$ has the advantage of being simple, low cost and high efficiency, which makes it very suitable for application in developing countries. $\mathrm{CW}$ can remove nitrogen, phosphorus, organic and inorganic pollutants therefore, it could prevent the spread of germs in water (Kivaisi, 2001). It can generally be divided into three types: surface-flow constructed wetland (SFCW), horizontal subsurface-flow constructed wetland (HSFCW) and vertical-flow constructed wetland (VFCW) according to the difference of bed fabric water method and flow mode (Cui et al., 2009). Vertical-Flow constructed wetland (VFCW) has been widely used because of its small area and high processing efficiency. Moreover, recent studies have shown that VFCW not only performs well in the treatment of BOD (biological oxygen demand) and TSS (total suspended solids), but also exhibits strong nitrification at low temperature and high load conditions (Cooper, 2005; Prochaska et al., 2007). Hydraulic load and organic 
load could affect the treatment efficiency of COD (chemical oxygen demand) and orthophosphate in VFCW (Sani et al., 2013). There are many studies on the purification effect of wetland plants, microorganisms and enzymes on wetland pollutants (Martens et al., 1992; Freeman et al., 1997; Kang et al., 1998; Shackle et al., 2000; Cheng et al., 2002). Among them, the enzyme activity of wetland soil directly affects the rate of material transformation and circulation in the environment, which plays a crucial role in maintaining the balance of the wetland ecosystem (Hill et al., 2006; Sun et al., 2018). Shackle (2006) demonstrated that extracellular enzymes can improve the biodegradation process. Soil enzymes together with microorganisms promote the conversion of substances. There are many factors influencing soil enzyme activity, including biological factors, soil factors and environmental factors (Duarte et al., 2008; Reboreda et al., 2008). In the study of soil enzymes, it was found that phosphatase can promote the hydrolysis of organophosphates. Urease is the hydrolase of C-N and catalase can convert hydrogen peroxide in the organism and matrix into water and oxygen. Sun (2018) studied the soil of reed community in Huishan karst wetland in Guilin, and found that the content of TOC (total organic carbon), TN (total nitrogen) and TP (total phosphorous) were significantly positively correlated with the activities of acid phosphatase, catalase, cellulase and other enzymes, which to some extent represented the changes in soil quality of reed community. Li (2015) proved that there was a significantly positive correlation between catalase activity and organic matter, total nitrogen, and alkali-hydrolyzed nitrogen in decanting wetlands in Baiguishan reservoir area, indicating that catalase activity was consistent with soil fertility changes. The above studies have proved that enzymes are necessarily related to nutrient cycling in soil. Therefore, it is necessary to study the relations among the substrate enzymes, pollutant removal and operating parameters to improve the research on wetland decontamination.

At present, most researchers improve the decontamination efficiency through aeration, parameter optimization, wetland plant selection and other methods (Green et al., 1998; Ouellet-Plamondon et al., 2006; Nivala et al., 2012; Abou-Elela et al., 2012; Guo et al.,2014; Ma et al., 2019; Pu et al., 2019; Kang et al., 2019). The research studies mainly concentrated on the aeration rate, aeration location, load size, the plant collocation on pollutants removal, but regarding the hydraulic load, organic load and combinatorial optimization in VFCW, and relationship between the pollutants removal and substrate enzyme activity of VFCW there are fewer investigations. Therefore, by carrying the different operation parameters of orthogonal test and monitoring the change of phosphatase, urease and catalase among the removal efficiency of TN, TP and COD (chemical oxygen demand), the effect of operation parameters combination optimization of VFCW on N, P, COD removal and the correlation between enzyme activity and pollutant removal was studied. This could provide theoretical basis for improving the decontamination of VFCW and using enzyme activity as the index to evaluate the purification effect of wetland.

\section{Materials and methods}

\section{Construction of the vertical-flow constructed wetlands}

In this experiment, PVC column was used to simulate the vertical-flow constructed wetland, with the following specifications: diameter of $30 \mathrm{~cm} \times$ height of $45 \mathrm{~cm}$. Two Hybrid Giant Napier were planted in each column. From bottom to top, the packing was 
$5 \mathrm{~cm}$ gravel layer and $35 \mathrm{~cm}$ mixed substrate (river sand + yellow soil). The experimental equipment was built in southwest China and shown in Figure 1.

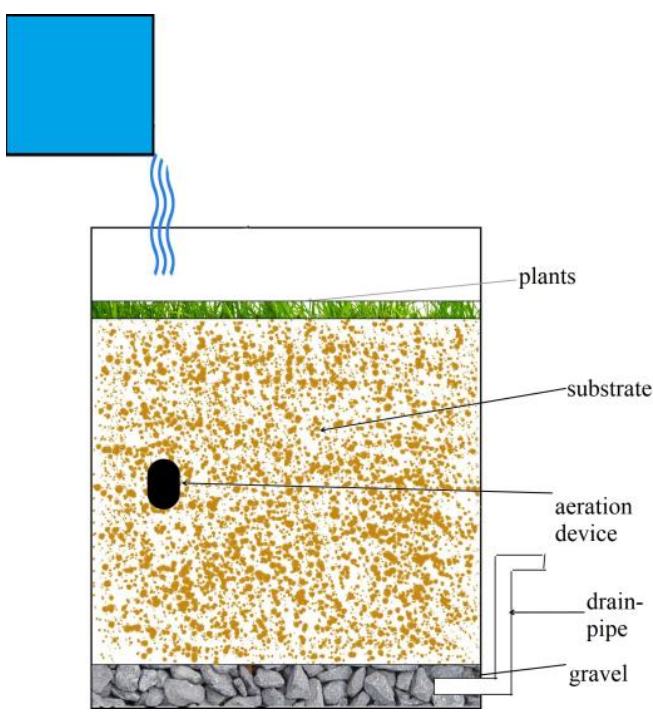

Figure 1. Simulation diagram of experimental equipment

\section{Experimental process}

The test settings were built outdoors in May $20^{\text {th }}$, and began to run in early June, and ended in September $20^{\text {th }}$. Quantitative peristaltic pump was used for continuous irrigation for $12 \mathrm{~h}$. Three factors (1: hydraulic load, 2: organic load, 3: aeration mode) were set for the test. Hydraulic load was set at 3 levels and the corresponding hydraulic load levels were 20,40 and $60 \mathrm{~cm} / \mathrm{d}$ respectively. In addition, the level of organic load was set at 3 levels as follows: $20 \mathrm{~g} /\left(\mathrm{m}^{2} \cdot \mathrm{d}\right), 40 \mathrm{~g} /\left(\mathrm{m}^{2} \cdot \mathrm{d}\right)$ and $60 \mathrm{~g} /\left(\mathrm{m}^{2} \cdot \mathrm{d}\right)$ (see Table 1 for details). At the same time, aeration mode was also set at 3 levels: continuous aeration, no aeration and intermittent aeration. The aeration device was installed with a timer to control the aeration time and the aeration mode, the specific operations were as follows: the continuous aeration in this experiment refers to the continuous aeration for $12 \mathrm{~h}$ during the irrigation period. The aeration volume was set to $1 \mathrm{~L} / \mathrm{min}$, and the total amount of aeration was $720 \mathrm{~L} / \mathrm{d}$. Intermittent aeration refers to aeration of $1 \mathrm{~h}$ every $3 \mathrm{~h}$ during irrigation, and the total aeration time was $3 \mathrm{~h}$. The aeration volume was set to 4 $\mathrm{L} / \mathrm{min}$, and the total amount of aeration was $720 \mathrm{~L} / \mathrm{d}$. Orthogonal design of three factors three levels, a total of 9 treatments, 3 repetitions, were presented in Table 1.

During the experiment period, the effluent water samples were collected every 10 day. After the experiment, soil samples were collected in each VFCW system and mixed to store.

\section{Influent quality}

The test sewage was synthetic simulated domestic sewage, the concentrations of TN and TP were $30-50 \mathrm{mg} / \mathrm{L}$ and $3-5 \mathrm{mg} / \mathrm{L}$, respectively. COD concentrations of the 9 treatments were $100 \mathrm{mg} / \mathrm{L}, 150 \mathrm{mg} / \mathrm{L}, 66 \mathrm{mg} / \mathrm{L}, 200 \mathrm{mg} / \mathrm{L}, 50 \mathrm{mg} / \mathrm{L}, 100 \mathrm{mg} / \mathrm{L}$, $300 \mathrm{mg} / \mathrm{L}, 100 \mathrm{mg} / \mathrm{L}, 33 \mathrm{mg} / \mathrm{L}$, and correspondingly the organic load were $20 \mathrm{~g} /\left(\mathrm{m}^{2} \cdot \mathrm{d}\right)$, 
$60 \mathrm{~g} /\left(\mathrm{m}^{2} \cdot \mathrm{d}\right), \quad 40 \mathrm{~g} /\left(\mathrm{m}^{2} \cdot \mathrm{d}\right), \quad 40 \mathrm{~g} /\left(\mathrm{m}^{2} \cdot \mathrm{d}\right), \quad 20 \mathrm{~g} /\left(\mathrm{m}^{2} \cdot \mathrm{d}\right), \quad 60 \mathrm{~g} /\left(\mathrm{m}^{2} \cdot \mathrm{d}\right), \quad 60 \mathrm{~g} /\left(\mathrm{m}^{2} \cdot \mathrm{d}\right)$, $40 \mathrm{~g} /\left(\mathrm{m}^{2} \cdot \mathrm{d}\right), 20 \mathrm{~g} /\left(\mathrm{m}^{2} \cdot \mathrm{d}\right)$.

Table 1. Orthogonal design of three factors at three levels

\begin{tabular}{|c|c|c|c|}
\hline Test number & Hydraulic load $(\mathrm{cm} / \mathrm{d})$ & Organic load $\left(g /\left(m^{2} \cdot d\right)\right)$ & Aeration mode \\
\hline $\mathrm{A}\left(\mathrm{H}_{1} \mathrm{O}_{1} \mathrm{~A}_{1}\right)$ & 20 & 20 & Continuous aeration \\
\hline $\mathrm{B}\left(\mathrm{H}_{2} \mathrm{O}_{3} \mathrm{~A}_{1}\right)$ & 40 & 60 & Continuous aeration \\
\hline $\mathrm{C}\left(\mathrm{H}_{3} \mathrm{O}_{2} \mathrm{~A}_{1}\right)$ & 60 & 40 & Continuous aeration \\
\hline $\mathrm{D}\left(\mathrm{H}_{1} \mathrm{O}_{2} \mathrm{~A}_{2}\right)$ & 20 & 40 & No aeration \\
\hline $\mathrm{E}\left(\mathrm{H}_{2} \mathrm{O}_{1} \mathrm{~A}_{2}\right)$ & 40 & 20 & No aeration \\
\hline $\mathrm{F}\left(\mathrm{H}_{3} \mathrm{O}_{3} \mathrm{~A}_{2}\right)$ & 60 & 60 & No aeration \\
\hline $\mathrm{G}\left(\mathrm{H}_{1} \mathrm{O}_{3} \mathrm{~A}_{3}\right)$ & 20 & 60 & Intermittent aeration \\
\hline $\mathrm{H}\left(\mathrm{H}_{2} \mathrm{O}_{2} \mathrm{~A}_{3}\right)$ & 40 & 40 & Intermittent aeration \\
\hline $\mathrm{I}\left(\mathrm{H}_{3} \mathrm{O}_{1} \mathrm{~A}_{3}\right)$ & 60 & 20 & Intermittent aeration \\
\hline
\end{tabular}

Orthogonal design of three factors three at levels: the three levels of hydraulic load were H1, H2 and H3 successively, namely: $20 \mathrm{~cm} / \mathrm{d}, 40 \mathrm{~cm} / \mathrm{d}$ and $60 \mathrm{~cm} / \mathrm{d}$; The three levels of organic load were $\mathrm{O} 1, \mathrm{O} 2$ and O3, namely: $20 \mathrm{~g} /\left(\mathrm{m}^{2} \cdot \mathrm{d}\right), 40 \mathrm{~g} /\left(\mathrm{m}^{2} \cdot \mathrm{d}\right), 60 \mathrm{~g} /\left(\mathrm{m}^{2} \cdot \mathrm{d}\right)$; The three levels of aeration level were A1, A2 and A3 successively, that was, continuous aeration, non-aeration and intermittent aeration

\section{Analytical methods}

For COD, TN and TP methods prescribed by national standards (State Environmental Protection Bureau, 1989) were adopted. Phosphatase, urease and catalase were tested by phenyl disodium phosphate, naismith colorimetry, and potassium permanganate titration methods, respectively (Guan, 1986).

\section{Statistical method}

The software of SPSS 17.0 and Excel 2007 were used to analyse the variance and calculate the mean and standard deviation of the correlation analysis. The main factors were analyzed by visual analysis ( $\mathrm{Li}$ and $\mathrm{Hu}, 2009$ ).

\section{Results and discussion \\ Removal efficiency of TN}

The removal efficiency of TN in nine VFCW systems have rapidly declined in different degree in the early days (Fig. 2). The main reason for this result is that the microorganisms are in the adaptive period and the overall activity is unstable. After the $12^{\text {th }}$ July, the removal effect of TN in 9 systems became stable, and the effect continued until the end of the experiment. It was also proved that the microorganisms meet the stable period in these systems. It is generally believed that the main mechanism of nitrogen removal is nitrification and denitrification by microorganisms (Gao, 2017). The removal rate of $\mathrm{TN}$ were $\mathrm{G}>\mathrm{A}>\mathrm{B}>\mathrm{C}>\mathrm{D}>\mathrm{H}>\mathrm{E}>\mathrm{I}>\mathrm{F}$. At the end of the experiment, there was a significant difference between $\mathrm{G}\left(\mathrm{H}_{1} \mathrm{O}_{3} \mathrm{~A}_{3}\right)$ and other treatments $(\mathrm{p}<0.05)$. It could be seen that increasing the organic load of inlet water and assisting intermittent artificial aeration are helpful for $\mathrm{TN}$ removal. The removal rate of $\mathrm{TN}$ in the 
system $\mathrm{G}$ was above $60 \%$. It was higher than in previous studies on the removal rate of TN (Vymazal, 2002; Arias et al., 2005; Liu et al., 2005).
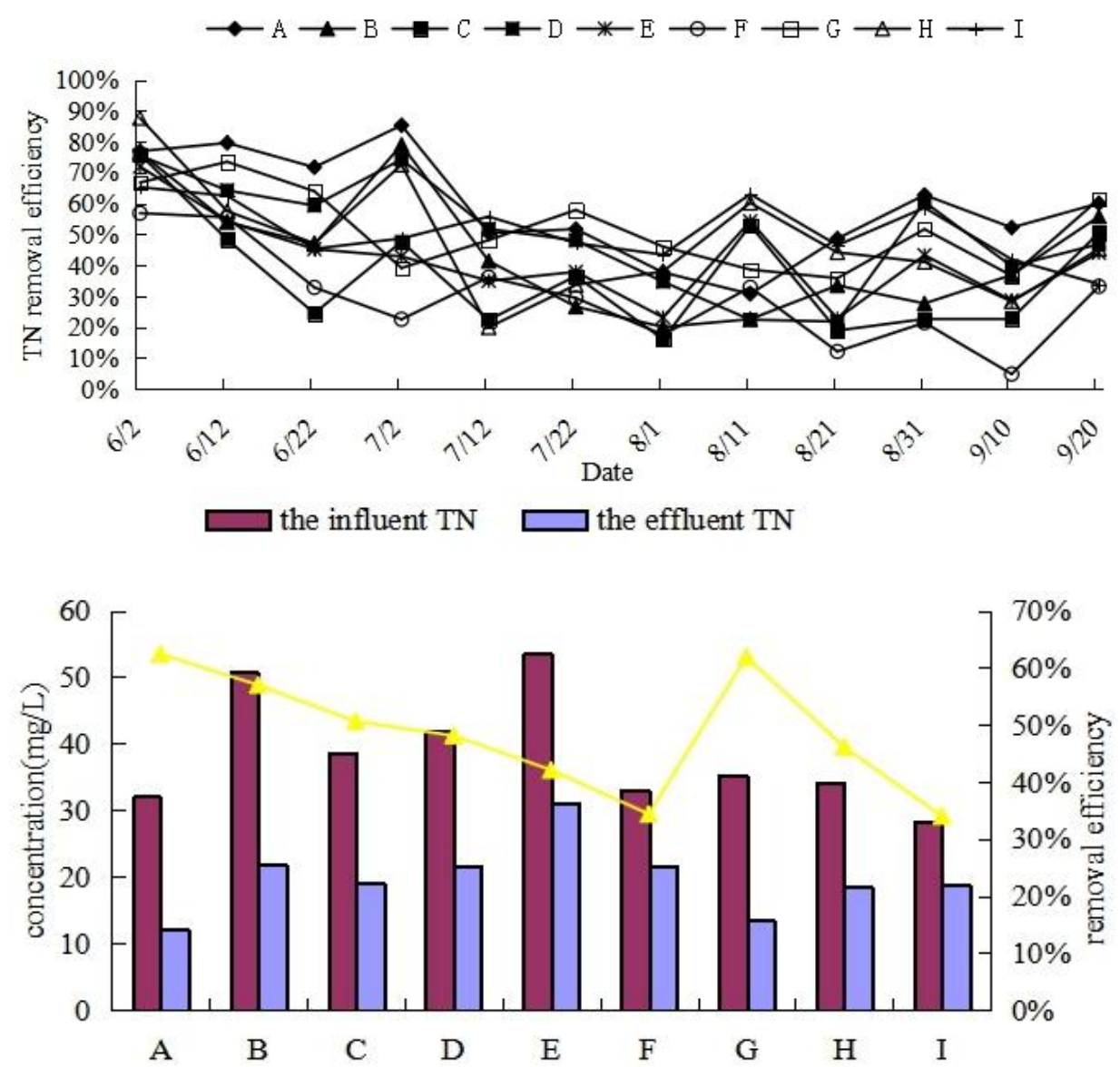

Figure 2. Removal efficiency of TN in systems

\section{Removal efficiency of TP}

As seen from Figure 3 , in the first week of the experiment, the removal rate of TP was high, ranging from $55 \%$ to $91 \%$. After one week, the TP removal rate dropped sharply, and after the $2^{\text {nd }}$ July, the TP removal rate was below $30 \%$ except for G. This influence continued to the end of the test, the removal rate of TP in the 9 treatments was $\mathrm{G}>\mathrm{A}>\mathrm{D}>\mathrm{H}>\mathrm{F}>\mathrm{E}>\mathrm{I}>\mathrm{B}>\mathrm{C}$, and the first two systems ( $\mathrm{G}$ and $\mathrm{A}$ ) were significantly different from other systems $(p<0.05)$. Brix and Arias $(2005)$ found that the average removal rate of $\mathrm{TP}$ in constructed wetlands was about $20 \%-30 \%$. The removal efficiency of TP was relatively low in this test, it could be due to more rain during the experiment or a slightly thinner substrate layer.

\section{Removal efficiency of COD}

The COD removal efficiency of these 9 treatments were excellent (Fig. 4). the removal rate of COD in these systems reached up to $60 \%$ 90\%, which were significantly higher than in other studies (Chazarenc et al., 2009; Tao et al., 2010; Li et al., 2011; Liu et al., 2011). The reason for this may be that the experiment was in summer, and the temperature was suitable for the growth of wetland plants and 
microorganisms, creating a favorable environment for COD removal. At the end of the experiment, D and $\mathrm{G}$ were as high as $90 \%$, this is due to the higher concentrations of influent in D and G. Liao (2002) studied the effect of constructed wetlands on organic matter treatment of pig farm wastewater, and found that the removal effect of COD and BOD in wetlands was significantly improved under the operation condition that the concentration of influent water was gradually increased. Because maintaining a high organic load can provide sufficient carbon source for wetland microorganisms, intermittent aeration could moderately increase DO, which is conducive to microbial growth and pollutant removal in the system.
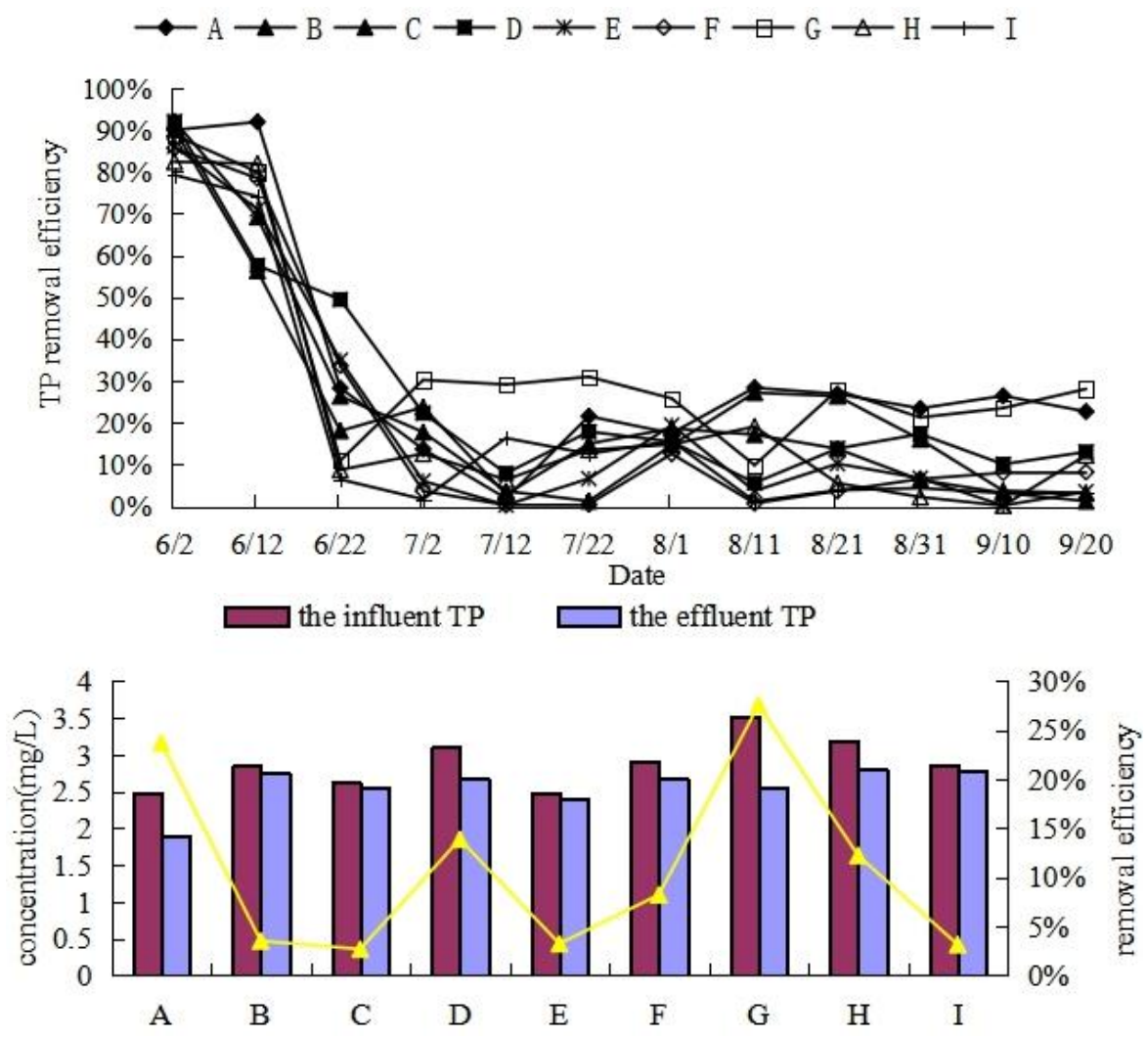

Figure 3. Removal efficiency of TP in systems

\section{Analysis of influence factor range of orthogonal test}

The main purpose of optimizing orthogonal experiment was to find the best values of the significant factors. Through the direct analysis of the orthogonal experiment of TN removal rate (Table 2), it can be seen that the influence size of the influence factor was: organic load > aeration level > hydraulic load, the optimal combination was $\mathrm{H}_{1} \mathrm{O}_{3} \mathrm{~A}_{1}$; Through the direct analysis of the orthogonal test of TP removal rate (Table 3), it can be seen that the influence size of the influence factor was: aeration level $>$ organic load > hydraulic load, the optimal combination is $\mathrm{H}_{1} \mathrm{O}_{3} \mathrm{~A}_{3}$; Through the direct analysis of the COD removal rate orthogonal experiment (Table 4), it can be seen that the influence size of the influence factor was the organic load $>$ aeration level $>$ hydraulic load, and the optimal combination is $\mathrm{H}_{1} \mathrm{O}_{3} \mathrm{~A}_{1}$. Combined with the orthogonal experiment of nitrogen, phosphorus and COD removal, the comprehensive and intuitive 
analysis showed that under the conditions of low hydraulic load, high organic load and aeration, the pollutant removal performance was outstanding. Taking economic factors into consideration, we chose low hydraulic load of $20 \mathrm{~cm} / \mathrm{d}$, high organic load of $60 \mathrm{~g} / \mathrm{m}^{2} \cdot \mathrm{d}$, and intermittent aeration, as the optimal scheme, which was $\mathrm{G}\left(\mathrm{H}_{1} \mathrm{O}_{3} \mathrm{~A}_{3}\right)$. It was suggested that the design of low hydraulic load, proper increase of organic load and auxiliary aeration could improve the decontamination capacity in vertical-flow constructed wetlands.
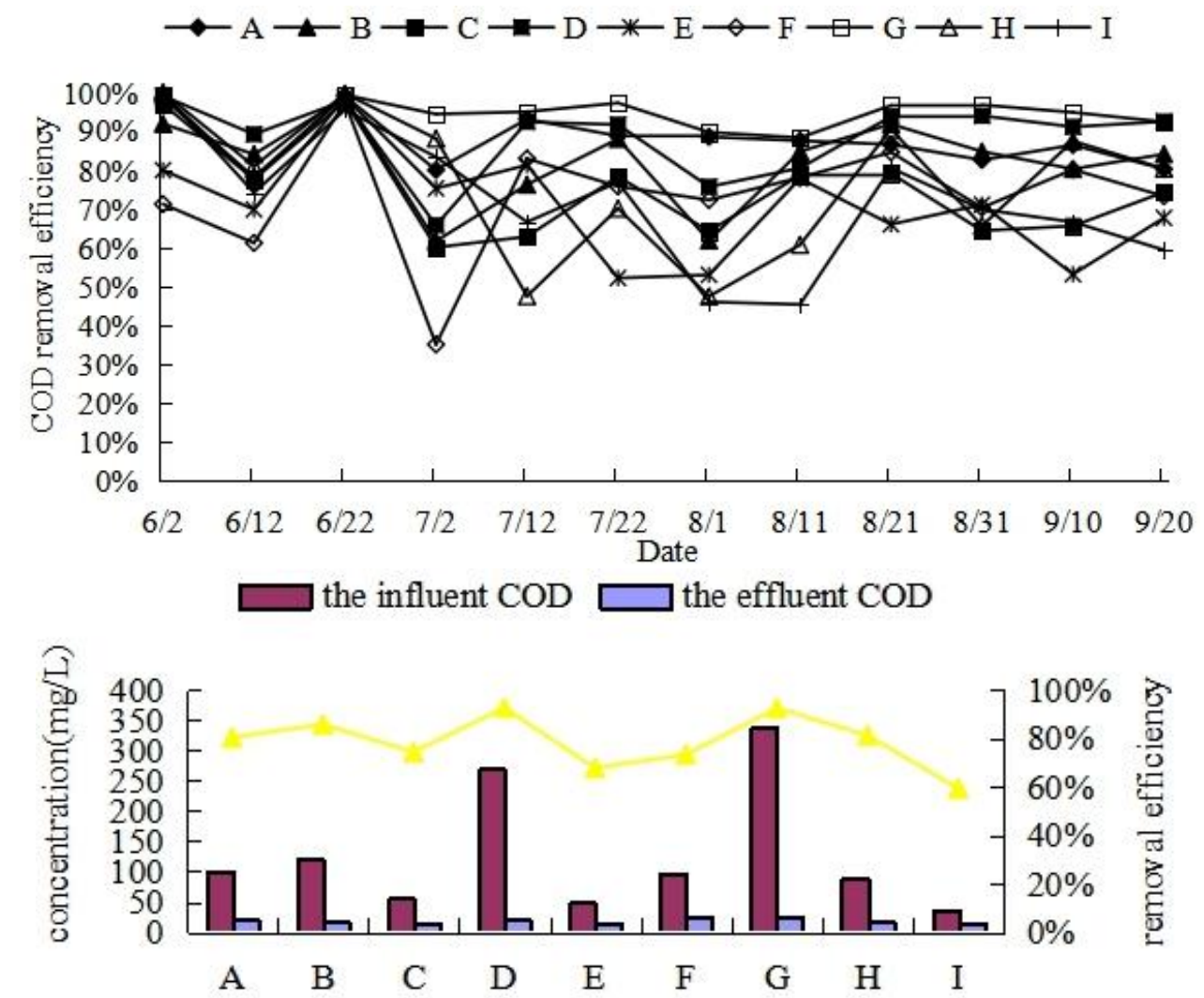

Figure 4. Removal efficiency of COD in systems

Table 2. Orthogonal experiment visual analysis of TN removal rates

\begin{tabular}{c|c|c|c}
\hline & Hydraulic load & Organic load & Aeration level \\
\hline K1 & 1.68 & 1.38 & 1.66 \\
K2 & 1.45 & 1.43 & 1.24 \\
K3 & 1.18 & 1.50 & 1.41 \\
R & 1.18 & 1.63 & 1.41 \\
\hline
\end{tabular}

Table 3. Orthogonal experiment visual analysis of TP removal rates

\begin{tabular}{llll}
\hline & Hydraulic load & Organic load & Aeration level \\
\hline K1 & 0.64 & 0.29 & 0.27 \\
K2 & 0.19 & 0.26 & 0.25 \\
K3 & 0.13 & 0.39 & 0.43 \\
R & 0.13 & 0.49 & 0.60 \\
\hline
\end{tabular}


Table 4. Orthogonal experiment visual analysis of COD removal rates

\begin{tabular}{llll}
\hline & Hydraulic load & Organic load & Aeration level \\
\hline K1 & 2.65 & 2.07 & 2.39 \\
K2 & 2.32 & 2.47 & 2.34 \\
K3 & 2.07 & 2.50 & 2.32 \\
R & 2.07 & 2.92 & 2.32 \\
\hline
\end{tabular}

$\mathrm{K} 1, \mathrm{~K} 2$ and $\mathrm{K} 3$ represent the average of the different factors in the same level results, the level of the factor influence size; $\mathrm{R}$ value is the difference between the maximum and minimum values and it represents the influence of this factor on the index. The greater the difference, the greater the impact

\section{The change of $\mathrm{pH}$ and $\mathrm{ORP}$}

From Figure 5 it can be seen that at the end of the test, the $\mathrm{pH}$ value of inlet and outlet water of these treatments did not change much, but the ORP value changed significantly. Artificially assisted aeration helped to maintain a relatively high ORP value. Among these systems, $G$ had the maximum ORP value at the end of the test. It indicated that intermittent aeration was more conducive to the reoxygenation in VFCW.

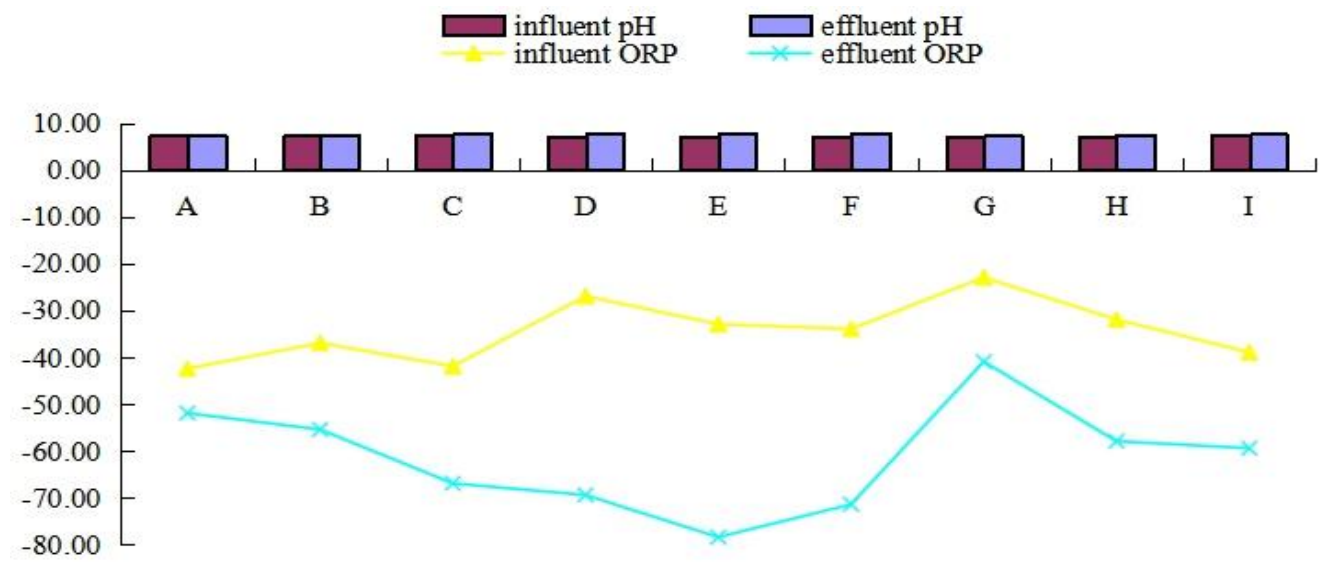

Figure 5. Changes in $p H$ and ORP

\section{Correlation analysis of substrate enzyme and sewage purification efficiency}

Correlation analysis of matrix enzyme and pollutant removal is showed in Table 5. It was showed that there was no significant correlation between phosphatase and TP removal rate, because the removal of phosphorus mainly depended on the adsorption of matrix, while microorganisms and plants only played a certain role (Dinges, 1982; Wu et al., 2001; Yan et al., 2007). The urease and the removal rate of TN have a significant correlation ( $\mathrm{p}<0.01$ ) (Wu et al., 2001; Huang et al., 2008). Catalase activity was also significantly correlated with $\mathrm{TN}$ removal rate $(\mathrm{p}<0.01)$. It indicated that there may be some relationship between catalase and nitrogen degradation. In addition, catalase and COD removal rate also showed a very significant correlation $(p<0.01)$. It may be associated with the characteristics of catalase, which was the enzyme that breaks down hydrogen peroxide in living organisms and substrates, converting it into water and oxygen. It could directly result in changes of ORP of matrix, and TN removal was mainly done by nitrification and denitrification, oxygen produced for the degradation of 
COD removal provided a good environment. In the future, advantages of high molecular biology methods can help an in-depth study on substrate enzyme contact with the inner mechanism of the pollutants degradation, and establish an efficient fast measurement of wetland pollutant removal ability.

Table 5. Correlation analysis of matrix enzyme and pollutant removal

\begin{tabular}{c|c|c|c|c|c|c|c}
\hline & & TN $(\%)$ & TP $(\%)$ & COD $(\%)$ & Urease & Phosphatase & Catalase \\
\hline \multirow{2}{*}{ Urease } & Pearson correlation & $.536^{* *}$ & -.202 & .308 & 1 & .071 & -.025 \\
& Significance (bilateral) & .004 & .312 & .350 & & .723 & .902 \\
\hline \multirow{2}{*}{ Phosphatase } & Pearson correlation & .154 & .286 & .327 & .071 & 1 & .306 \\
& Significance (bilateral) & .443 & .147 & .026 & .723 & & .121 \\
\hline \multirow{2}{*}{ Catalase } & Pearson correlation & $.791^{* *}$ & .223 & $.523^{* *}$ & -.025 & .306 & 1 \\
& Significance (bilateral) & .000 & .263 & .005 & .902 & .121 & \\
\hline
\end{tabular}

*Significantly correlated at the level of 0.05 (bilateral). **Significantly correlated at the level of 0.01 (bilateral)

\section{Conclusion}

(1) In the VFCW, the order of influence on the removal effect of TN and COD were as follows: organic load > aeration method > hydraulic load; Based on the comprehensive analysis, it was concluded that for the VFCW system, maintaining a reasonable concentration of organic matter inflow, relatively low hydraulic load and auxiliary aeration are not only achieve the best removal effect, but also extend the life of wetland. It could provide theoretical support for the construction and management of VFCW in the future.

(2) Urease and catalase showed a very significant correlation with TN removal. Catalase may provide a good degradation environment for COD removal and it provide basic data for further study on the relationship between matrix enzyme and pollutant removal.

Acknowledgements. This study was supported by Guizhou Normal Colleges and Technology Top-Notch Talent Support Program Project (qianjiaohe KY [2016]097), Guizhou Provincial Science and Technology Plan Project (qiankeheLH [2016]7283), Doctoral Fund Project (asubsjj201607). The authors would like to thank for their financial support.

\section{REFERENCES}

[1] Abou-Elela, S. I., Hellal, M. S. (2012): Municipal wastewater treatment using vertical flow constructed wetlands planted with Canna, Phragmites and Cyprus. - Ecological Engineering 47: 209-213.

[2] Arias, C. A., Brix, H., Marti, E. (2005): Recycling of treated effluents enhances removal of total nitrogen in vertical flow constructed wetlands. - Journal of Environmental Science Health 40(6-7): 1431-1443.

[3] Brix, H., Arias, C. A. (2005): The use of vertical flow constructed wetlands for on-site treatment of domestic wastewater: new Danish guidelines. - Ecological Engineering 25: 491-500.

[4] Chazarenc, F., Gagnon, V., Comeau, Y., Brissona, J. (2009): Effect of plant and artificial aeration on solids accumulation and biological activities in constructed wetlands. Ecological Engineering 35: 1005-1010. 
[5] Cheng, S. P., Wu, Z. B., Kuang, Q. J. (2002): Macrophytes in artificial wetland. - Journal of Lake Sciences 14(2): 179-184.

[6] Cooper, P. (2005): The performance of vertical flow constructed wetland systems with special reference to the significance of oxygen transfer and hydraulic loading rates. Water Science Technology 51(9): 81-90.

[7] Cui, L. H., Lu, S. Y. (2009): Constructed Wetland Technology for Sewage Treatment. Chemical Industry Press, Beijing.

[8] Dinges, R. (1982): Natural Systems for Water Pollution Control. - Van Nostrand Reinhold Co. Press, New York.

[9] Duarte, B., Reboreda, R., Cacador, I. (2008): Seasonal variation of extracellular enzymatic activity (EEA) and its influence on metal speciation in a polluted salt marsh. Chemosphere 73: 1056-1063.

[10] Freeman, C., Lock, M. A., Hughes, S., Reynolds, B. (1997): Nitrous oxide emissions and the use of wetlands for water quality amelioration. - Environmental Science \& Technology 31(8): 2438-2440.

[11] Gao, Y. (2017): The Process and Mechanism of Electrolysis Intensified Constructed Wetland to Remove Nitrogen and Phosphorus. - Nanjing University, Nanjing.

[12] Green, M., Friedler, E., Safrai, I. (1998): Enhancing nitrification in vertical flow constructed wetland utilizing a passive air pump. - Water Research 32(12): 3513-3520.

[13] Guan, S. Y. (1986): Soil Enzyme and Its Research Method. - Agriculture Press, Beijing.

[14] Guo, Y. Y., Yang, S. Y., Huang, Y., Zhang, J., Fan, J. L. (2014): Effect of intermittent aeration on performance of nitrogen removal in domestic wastewater treatment by subsurface constructed wetland. - Chinese Journal of Environmental Engineering 8(4): 1405-1409.

[15] Hill, B. H., Elonen, C. M., Jicha, T. M., Cotter, A. M. (2006): Sediment microbial enzyme activity as an indicator of nutrient limitation in Great Lakes coastal wetlands. Freshwater Biology 51: 1670-1683.

[16] Huang, J., Wang, S. H., Yan, L., Liu, Y., Wang, F. (2008): Distribution characteristic of urease activity in subsurface constructed wetlands. - Journal of Southeast University (Natural Science Edition) 1: 166-169.

[17] Kang, H., Freeman, C., Lee, D., Mitsch, W. J. (1998): Enzyme activities in constructed wetlands: implication for water quality amelioration. - Hydrobiologia 368: 231-235.

[18] Kang, X. R., Liu, Y. L., Zhou, Y. X., Su, Y. (2019): Studies on intermittent aeration enhancing nitrogen removal of constructed wetland at low temperature. - Forest Engineering 35(3): 74-77.

[19] Kivaisi, A. K. (2001): The potential for constructed wetlands for wastewater treatment and reuse in developing countries: a review. - Ecological Engineering 16 (4): 545-560.

[20] Li, C. H., Wang, W. Q., Ni, L. X., Li, X. D., Li, Y., Zhao, X. L. (2011): Effect of artificial aeration on the operation efficiency of vertical subsurface flow constructed wetland. - Journal of Hohai University (Natural Sciences Edition) 39(3): 259-263.

[21] Li, Y. J., Zhao, G. Q., Peng, S. L., Chen, C. D., Liao, B. H., Liu, D. D. (2017): Study on microbial and enzyme activities in soils dried after extreme drought events in wetlands. Journal of Tianjing University of Science \& Technology 32(5): 55-59.

[22] Li, Y. Y., Hu, C. R. (2009): Experiment Design and Data Processing. - Chemical Industry Press, Beijing.

[23] Liao, X. D., Luo, S. M. (2002): Treatment effect of constructed wetland on organic matter in wastewater from pig farm. - Chinese Journal of Applied Ecology 13(1): 113-117.

[24] Liu, F. F., Wang, D. J. (2011): Effect of outlet position and plant species on rural domestic sewage purification in engineered vertical flow wetland. - Chinese Journal of Eco-Agriculture 19(4): 912-917.

[25] Liu, W., Dahab, M. F., Surampalli, R. Y. (2005): Nitrogen transformations modeling in subsurface-flow constructed wetlands. - Water Environment Research 77: 246-258. 
[26] Ma, Z., Cui, Y. L., Guo, C. Q., Wan, D., Liu, F. P., Ma, L. H. (2019): Optimization of design parameters of surface flow constructed wetland based on hydraulic performance and pollutant purification effect. - Transactions of the Chinese Society of Agricultural Engineering 35(12): 157-164.

[27] Martens, D. A., Johanson, J. B., Frankenberger, W. T. (1992): Production and persistence of soil enzymes with repeated addition of organic residues. - Soil Science 153: 53-61.

[28] Nivala, J., Knowles, P., Dotro, G., García, J., Wallace, S. (2012): Clogging in subsurfaceflow treatment wetlands: measurement, modeling and management. - Water Research 46: 1625-1640.

[29] Ouellet-Plamondon, C., Chazarenc, F., Comeau, Y., Brisson, J. (2006): Artificial aeration to increase pollutant removal efficiency of constructed wetlands in cold climate. Ecological Engineering 27 (3): 258-264.

[30] Prochaska, C. A., Zouboulis, A. I., Eskridge, K. M. (2007): Performance of pilot-scale vertical-flow constructed wetlands, as affected by season, substrate, hydraulic load and frequency of application of simulate urban sewage. - Ecological Engineering 31: 57-66.

[31] Pu, S., Xu, D., Tong, W. J., Wang, Q., Chen, D. S., Cheng, X., Zhang, T., Zhang, Y., Wu, Z. B. (2019): Study on nitrogen removal efficiency of vertical subsurface constructed wetland by aeration location. - Industrial Water Treatment 39(1): 91-95.

[32] Reboreda, R., Cacador, I. (2008): Enzymatic activity in the rhizosphere of Spartina maritima: potential contribution for phytoremediation of metals. - Marine Environmental Research 65(1): 77-84.

[33] Sani, A., Scholz, M., Babatunde, A., Wang, Y. (2013): Impact of water quality parameters on the clogging of vertical-flow constructed wetlands treating urban wastewater. - Water, Air, \& Soil Pollution 224(3): 1641.

[34] Shackle, V. J., Freeman, C., Reynolds, B. (2000): Carbon supply and the regulation of enzyme activity in constructed wetlands. - Soil Biology and Biochemistry 32: 19351940.

[35] Shackle, V. J., Freeman, C., Reynolds, B. (2006): Exogenous enzyme supplements to promote treatment efficiency in constructed wetlands. - Science of the Total Environment 361: 18-24.

[36] State Environmental Protection Bureau (1989): Methods for Monitoring and Analysis of Water and Wastewater. 3rd Ed. - China Environmental Sciences Press, Beijing.

[37] Sun, Y. J., Xu, G. P., Shen, Y. Y., Pu, G. Z., Li, Y. Q., Zhou, C. M., Mo, L., Li, Y. Q. (2018): Soil Enzyme Activities of Phragmites australis Community Area in Huixian Karst Wetland, Guilin. - Wetland Science 16(2): 196-203.

[38] Tao, M., Fu, G. P., He, F., Xu, D., Cheng, S. P., Wu, Z. B. (2010): Study on optimization of aeration condition in integrated vertical-flow constructed wetland. - Technology of Water Treatment 36(10): 57-60.

[39] Vymazal, J. (2002): The use of sub-surface constructed wetlands for wastewater treatment in the Czech Republic: 10 years experience. - Ecological Engineering 18: 633646.

[40] Wu, Z. B., Liang, W., Cheng, S. P., He, F., Fu, G. P., Chen, H. R., Deng, J. Q., Zhang, F. C. (2001): Studies on correlation between the enzymatic activities in the rhizosphere and purification of wastewater in the constructed wetland. - Journal of Environmental Sciences 21(5): 622-624.

[41] Yan, Z. S., Wang, S. H. (2007): An exploratory discussion of substrate for phosphorus removal potential for constructed wetland. - Ecology and Environment 16(2): 661-666. 